\title{
Hélène Cixous's The Perjured City: Nonprosecution Alternatives to Collective Violence
}

Susan Ayres

Texas A\&M University School of Law, sayres@law.tamu.edu

Follow this and additional works at: https://scholarship.law.tamu.edu/facscholar

Part of the Criminal Law Commons, Criminal Procedure Commons, and the Legal Profession Commons

\section{Recommended Citation}

Susan Ayres, Hélène Cixous's The Perjured City: Nonprosecution Alternatives to Collective Violence, 9 N.Y. City L. Rev. 1 (2005).

Available at: https://scholarship.law.tamu.edu/facscholar/189

This Article is brought to you for free and open access by Texas A\&M Law Scholarship. It has been accepted for inclusion in Faculty Scholarship by an authorized administrator of Texas A\&M Law Scholarship. For more information, please contact aretteen@law.tamu.edu. 


\title{
HÉLÈNE CIXOUS'S THE PERJURED CITY: NONPROSECUTION ALTERNATIVES TO COLLECTIVE VIOLENCE
}

\author{
Susan Ayres*
}

When people begin to believe that organized society is unwilling or unable to impose upon criminal offenders the punishment they "deserve," then there are sown the seeds of anarchy-of self-help, vigilante justice, and lynch law. ${ }^{1}$

In instances of collective violence-apartheid in South Africa, mass killings in Rwanda, and other crimes against humanity such as slavery-what response provides justice? In Rwanda it was estimated that it would take 120 years for the court to prosecute all perpetrators of genocide. ${ }^{2}$ How can justice be achieved under such a system? Legal justice through prosecution would be unjust. This failure to achieve justice through conventional means therefore opens the possibility of nonprosecution alternatives involving forgiveness.

Hélène Cixous's play about forgiveness as an alternative to criminal prosecution, The Perjured City: Or, the Awakening of the Furies, ${ }^{3}$ was written in response to an actual case of failed justice in France, known as the Bad Blood Scandal. The play provides a model of forgiveness and a forum for public catharsis. Cixous, the preeminent French theorist concerned with social justice, who has written over forty books and one hundred articles, has stated, "legal justice is not ideal justice. It is a legally unjust justice."4 Her

* Associate Professor, Texas Wesleyan University School of Law. Thanks to Teresa Godwin Phelps; to my present and former colleagues, Aric Short, Ben Davis; Cynthia Fountaine, Michael Green, and Nancy Myers; and to participants in the November 2002 Subversive Legacies Conference held in Austin, Texas for invaluable criticism. My appreciation goes to David Clem, Cally Conklin, William Fontenot, and Rebecca Eaton for research assistance and to Texas Wesleyan University School of Law for financial support of this project.

1 Gregg v. Georgia, 428 U.S. 227, 238 (1976) (Marshall, J., dissenting) (quoting Furman v. Georgia, 408 U.S. 238, 308 (1972) (Stewart, J., concurring)), quoted in Robert C. Solomon, Justice v. Vengeance: On Law and the Satisfaction of Emotion, in THE Passions of LAW 123, 131 (Susan A. Bandes ed., 1999).

2 Pernille Ironside, Rwandan Gacaca: Seeking Alternative Means to Justice, Peace and Reconciliation, 15 N.Y. INT'L L. REv. 31, 32 (2002).

3 Hélène Cixous, The Perjured City: Or, the Awakening of the Furies, in Selected Plays of HÉlène Cixous 89 (Eric Prenowitz ed., Bernadette Fort trans., 2004) [hereinafter Cixous, The Perjured City].

4 Bernadette Fort, Theater, History, Ethics: An Interview with Hélène Cixous on The 
play addresses the legal system's failure to hold accountable several French physicians who exposed hemophiliacs to Human Immunodeficiency Virus (HIV). The background of the Bad Blood Scandal is discussed in Part One of this Article. Cixous viewed the scandal as an instance of genocide and responded by writing The Perjured City-a play that exposes the injustice of the legal system.

Part Two analyzes this play, in which the mother of dead hemophiliac children wants to avenge their deaths. The responsible doctors are hounded by the Greek Furies, who have been silently observing the legal system's injustice since they went underground to be benevolent goddesses after the trial of Orestes in Aeschylus's play The Eumenides. ${ }^{5}$ Cixous's play calls for the Furies' return, but her play does not depict simple revenge. Rather, her play depicts a ceremony of confession and forgiveness.

Parts Three and Four of this Article summarize the goals and the theoretical debate surrounding nonprosecution alternatives such as the ceremony found in The Perjured City. Typically, nonprosecution alternatives attempt to provide therapeutic goals or restorative justice. Many theoretical questions arise when forgiveness is also sought as part of restorative justice. Should forgiveness be unconditional? Should forgiveness be sought in the public forum? Does forgiveness lead to forgiving? After considering these questions, Part Five of this Article discusses an example of nonprosecution alternatives in the South African Truth and Reconciliation Commission (TRC), which was a likely model for Cixous, who had previously written a book on Nelson Mandela. ${ }^{6}$ This Article concludes by arguing that while there is no simple answer to the question of what is just justice, society must remain open to nonprosecution alternatives and restorative justice, especially in the context of extraordinary crimes.

\section{The Bad Blood Scandal: "Consolation and Justice Do Not ExIsT"7}

The French Bad Blood Scandal served as the impetus for The

Perjured City, or the Awakening of the Furies, 28 New Literary History 425, 442 (1997).

5 Aeschylus, The Eumenides, in The Oresteia (Robert Fagles trans., 1977). The Oresteia trilogy consists of Agamemnon, The Libation Bearers, and The Eumenides.

6 Hélène Cixous, Manna: For the Mandelstams for the Mandelas (Catherine A.F. MacGillivray trans., 1994) [hereinafter Cixous, MANNA].

7 Hélène Cixous, Enter the Theatre, in Selected Plays of Hélène Cixous 25, 26 (Eric Prenowitz ed., Brian J. Mallet trans., 2004) [hereinafter Cixous, Enter the Theatre]. 
Perjured City, written by Cixous for the experimental troupe Theatre du Soleil, with which she had been associated since the early $1980 \mathrm{~s}^{8}$ The director of the troupe, Ariane Mnouchkine, often suggested contemporary events as subject matter for plays. ${ }^{9}$ The troupe's goal or "dream" consisted of "telling in such a way that something will move in reality. If not change-which would be enormously presumptuous-then at least be recalled, ressuscitated [sic], delivered from silence." 10 Mnouchkine and Cixous searched for subject matter based on events that "come to afflict us cruelly, having taken us (we the public, the citizens) by surprise or treachery, leave us wounded, powerless, appalled."11 Indeed, Cixous initially resisted the Bad Blood Scandal as subject matter for a play because it was so "monstrous." 12

She overcame her initial resistance, however, and wrote The Perjured City. As most French spectators would know, the blood market had a unique history. Since the time of the French Resistance and World War II, the donation of blood in France had been anonymous, voluntary, and heroic. ${ }^{13}$ French blood was presumed to be pure-that is, until the advent of HIV. ${ }^{14}$ By 1985, half the hemophiliacs in Paris had become infected with HIV by transfusion. ${ }^{15}$ The concentrates used by hemophiliacs were especially at risk of HIV contamination because they were made from pools of 2000 to 20,000 plasma donors. ${ }^{16}$ The concentrates, known as Factors VIII and IX, were available in powder form and could be stored up to two years. ${ }^{17}$ Of France's fractionation plants that produced blood products, including Factors VIII and IX, the Paris plant was the largest, producing $70-80 \%$ of the blood products sold in France. ${ }^{18}$ Unfortunately, the French medical community initially ignored the risk of HIV transmission in blood because France, along with many other countries, considered HIV an Amer-

8 Eric Prenowitz, On Theatre: An Interview with Hélène Cixous, in Selected Plays of Hélène Gixous 1, 1 (Eric Prenowitz ed., 2004).

9 Cixous, Enter the Theatre, supra note 7, at 27.

$10 \mathrm{Id}$

11 Id. at 28.

12 Prenowitz, supra note 8, at 17.

13 Jane Kramer, Bad Blood, New Yorker, Oct. 11, 1993, at 74, 75; Michael Trebilcock et al., Do Institutions Matter? A Comparative Pathology of the HIV-Infected Blood Tragedy, 82 VA. L. REv. 1407, 1428 (1996).

14 Kramer, supra note 13, at 75; Trebilcock, supra note 13, at 1449 .

15 Trebilcock, supra note 13, at 1407; Kramer, supra note 13, at 95.

16 Trebilcock, supra note 13, at 1422.

17 Kramer, supra note 13, at 88.

18 Trebilcock, supra note 13, at 1429. 
ican disease, and France presumed its own blood to be pure. ${ }^{19}$

Michel Garetta, director, and Jean-Pierre Allain, head scientist, of the Paris blood center caused hundreds of hemophiliacs to die when the blood center delayed screening donors and implementing the heat technology that would have killed the virus. ${ }^{20}$ Some viewed the Bad Blood Scandal to have occurred because Garetta and Allain were more interested in cornering the European market by producing clotting concentrates than in assuring the quality of the concentrates. ${ }^{21}$ For instance, although an American supplier of plasma warned the Paris director to use heated plasma and the American Center for Disease Control announced that heating was absolutely necessary, the Paris center did not heat plasma for another nine months. ${ }^{22}$ The Paris doctors also did not import heated concentrate or recall backstock, which had a twoyear shelf life. ${ }^{23}$ Instead, they tried to dump the contaminated blood in foreign markets and in hospitals. ${ }^{24}$ And if these actions were not bad enough, hemophiliacs also became unnecessarily infected because government officials stalled in approving an American HIV test (the Abbott test) until the French test (the Pasteur test) had been approved-again, to benefit the French market. ${ }^{25}$

The resulting statistics are gruesome. Out of a total of 3000 French hemophiliacs, almost half were infected by the time the American Abbott test had been approved by the Food and Drug Administration (FDA) in March of $1985 .{ }^{26}$ Between March and October, when the French Pasteur test was implemented and blood concentrate was heated, about 100 to 300 hemophiliacs were contaminated. ${ }^{27}$ By that time, $71 \%$ of all hemophiliacs were infected in Paris, and $90 \%$ of Allain's private patients were infected..$^{28}$ Non-hemophiliacs were also infected (about 1500 people), and

19 Kramer, supra note 13, at 75; Trebilcock, supra note 13, at 1449; Monika Steffen, The Nation's Blood: Medicine, fustice, and the State in France, in Blood Feuds: Aids, Blood, and the Politics of Medical Disaster 95, 96 (Eric A. Feldman \& Ronald Bayer eds., 1999).

20 Kramer, supra note 13 , at $84-85$.

21 Id. at $77,81,90$.

22 Id. at $84,90$.

23 Id. at 85,88 .

$24 I d$. at $82-85$.

25 Id. at 90.

26 Id. at 85, 90; Steffen, supra note 19, at 109; Umberto Izzo, Blood, Bureaucracy and Law: Responding to HIV-Tainted Blood in Italy, in Blood Feuds: AIDS, BLOOD, AND THE Politics of Medical Disaster 213, 220 (Eric A. Feldman \& Ronald Bayer eds., 1999);

Trebilcock, supra note 13, at 1407.

27 Kramer, supra note 13 , at 90.

28 Id. at 95. 
from March through October, about six to ten people a day were contaminated. ${ }^{29}$

In contrast, during the same time, Britain had seventy-five total cases of infection by blood transfusion. ${ }^{30}$ In Belgium, only $7 \%$ of hemophiliacs were infected because Belgian hemophiliacs did not take factor concentrates preventively, whereas the French hemophiliacs took extra concentrates so as to lead a normal life. ${ }^{31}$ U.S. statistics are almost as bad as France's: About 10,000 hemophiliacs, or about $50 \%$ of hemophiliacs in the United States, were infected by transfusion between 1978 and $1984 .^{32}$ The difference is that the United States did not have high-level officials who unnecessarily delayed instituting screening or heating technology. In fact, the United States was one of the countries that quickly responded by discovering the risk, warning high-risk donors, licensing heat-treated products, and adopting HIV testing. ${ }^{33}$

Japan's blood scandal, on the other hand, was unfortunately almost as bad as France's: Of nearly 5000 Japanese hemophiliacs, over 1800 were infected by transfusion. ${ }^{34}$ A government advisory group in Japan ignored risks to the blood supply for hemophiliacs, and, like officials in France, delayed heating the blood products. ${ }^{35}$ Japanese plaintiffs sued the pharmaceutical companies and the Ministry of Health and Welfare, demanding an apology. ${ }^{36} \mathrm{~A}$ civil settlement was not reached for seven years, and it was followed by a criminal investigation. ${ }^{37}$ As part of the civil settlement, the health and welfare minister Naoto Kan and the heads of all the pharmaceutical companies apologized. ${ }^{38}$ The president of one of the biggest companies Green Cross spent ten minutes kneeling with his head bowed to the floor, apologizing. ${ }^{39}$ After the criminal investigation, the health minister at the time of the scandal was given a

29 Id. at 90.

30 Id. at 91 .

31 Id. at $91,95$.

32 Trebilcock, supra note 13, at 1407.

33 Id. at 1477.

34 Anthony Spaeth, Ceremony of Blood, TIME INT'L, Mar. 25, 1996, at 31.

35 Eric A. Feldman, Deconstructing the Japanese HIV Scandal (Japan Pol'y Res. Inst., Working Paper No. 30, 1997), http://www.jpri.org/publications/workingpapers/wp 30.html.

36 Id. at 4-5 (also noting the taboo of suing the Japanese Red Cross (JRC) because "the honorary chair of the JRC has since the Meiji period been a member of the Japanese royal family, which has bestowed a peculiar kind of sanctity on the organization").

37 Id. at 5-6.

38 Id. at 6.

39 Spaeth, supra note 34 . 
one-year suspended sentence, and executives of Green Cross were given sentences ranging from sixteen months to two years. ${ }^{40}$

Similarly in the early 1990 s, French hemophiliacs successfully brought 2000 civil suits and received fairly large judgments. ${ }^{41}$ They also successfully sued the state for its failure to prohibit the distribution of unheated products. ${ }^{42}$ But the hemophiliacs, their families, and the public were so outraged by the culpability of the doctors and government ministers, that the doctors were eventually tried on criminal charges. ${ }^{43}$ The defense of the doctors was dans le doute - that "doctors in doubt do not risk lives unless they are acting in emergencies." ${ }^{4}$ In 1992, Garetta and Allain were tried for the misdemeanors of merchandising fraud. ${ }^{45}$ Garetta received the maximum four-year sentence, and Allain received a four-year sentence, with two years suspended. ${ }^{46}$ The court also entered an award of nine million French francs. Two government officials, Jacques Roux, the Director of General Health, and Robert Netter, Director of the National Laboratory of Health, were subsequently tried and found guilty of the misdemeanors of non-assistance to persons in danger, for failing to stop distribution of unheated concentrate, and failure to authorize the American Abbott test. ${ }^{47}$ Roux (the French equivalent of the American Surgeon General) received a four-year suspended sentence, and Netter (the French equivalent of the head of the FDA) received a one-year suspended sentence. ${ }^{48}$ The highest court affirmed in 1994, but held that the doctors should not have been tried for misdemeanors; rather for the felony of poisoning. Therefore, the court increased the monetary award from nine million to fifteen million French francs. ${ }^{49}$ When the doctors were not tried for a felony, public outrage flared up. Half of France's hemophiliacs had been infected, and yet, legal justice was unjust.

Because justice was not served through criminal prosecution, Ariane Mnouchkine persuaded Cixous to write The Perjured City, a play dedicated to the hemophiliacs. Theatre du Soleil first pro-

40 BBC News, Japan Blood Scandal Official Convicted, Sept. 28, 2001, http://news. bbc.co.uk/1/hi/world/asia-pacific/1568626.stm.

41 Steffen, supra note 19 , at 116-17.

$42 I d$. at 117.

$43 \mathrm{Id}$. at 117-18.

44 Kramer, supra note 13 , at 77,81 .

45 Id. at $81-82$.

$46 \mathrm{Id}$. at 82 .

47 Id. at 81 .

48 Id. at 82.

49 Steffen, supra note 19 , at 119. 
duced it in Paris in October 1994 and then performed it on tour in Europe the following year. ${ }^{50}$ Altogether, 51,000 people attended the production. ${ }^{51}$ An English translation was performed in 1997 at the Northwestern University Theatre. ${ }^{52}$

After the French production of The Perjured City in 1995, the Paris Prosecutor investigated more government officials, including the Socialist Prime Minister during the time of the Bad Blood Scandal Laurent Fabius, his Health Secretary Edmond Hervé, and his Social Affairs Minister Georgina Dufoix. ${ }^{53}$ They were ultimately tried in 1999 for involuntary manslaughter and involuntary bodily injury. ${ }^{54}$ Fabius and Dufoix were acquitted; Hervé was convicted but did not receive a sentence. ${ }^{55}$ The impact of the Bad Blood Scandal has been described as "a redefinition of the symbolic value of blood .... . [T] he blood sector is no longer viewed as the noble medical expression of social solidarity but rather as a technical, consumer-oriented domain. Blood has lost its special status as a 'part of the human body.' It has descended into the category of normal drugs." 56

The preface to The Perjured City, a short essay entitled Our Bad Bloods, alludes to the symbolic value of blood in both literature and in the Bad Blood Scandal. Cixous wrote:

'Blood' once spilled can never be spilled again .... Leaning over the bank of the red river of terrifying fate, powerless to retain life that flows away, all the poets watched, from century to century, tragic horror run its course. Hear them wail their indignant hymn, Aeschylus, Shakespeare, Balzac, Hugo, horribly fascinated by the carnage wrought by man, and the city. In the streets, one sinks ankle-deep into the red mud. ${ }^{57}$

In this introductory essay, Cixous also describes the Bad Blood Scandal as allegory:

Here is the story: one day, lambs learned in spite of themselves that their shepherds were wolves. Wounded, losing their blood, they lie dying. Can this be? Did those who cared for them kill them? No!? Yes! Who can imagine such a thing? We who see

50 Premières in Selected Plays of Hélène Cixous, 223, 224 (Eric Prenowitz ed., 2004).

51 Id.

52 Cixous, The Perjured City, supra note 3, at 184 n.2 (translator's note).

53 Steffen, supra note 19, at 120.

54 Id. at 121.

55 Craig R. Whitney, Top French Officials Cleared over Blood with AIDS Virus, N.Y.

Times, Mar. 10, 1999, at Al.

56 Steffen, supra note 19, at 123.

57 Cixous, The Perjured City, supra note 3, at 89. 
the victims expire one by one, it is with dread and stupefaction

that we are forced to admit the worst: cut-throat shepherds. ${ }^{58}$

The play begins after the criminal justice system's failure to deal with these "cut-throat shepherds" in a just fashion. Grounded in horrific real world events, the play proceeds to both condemn the criminal justice system's failure and envision an alternative system of justice.

\section{The Perjured City. "The Sickness of the Kingdom"59}

In order to write the play, Cixous interviewed hemophiliacs and doctors. ${ }^{60}$ She had to find a way to accomplish the impossibly difficult task of writing a play for an audience that might include people dying from the very problem the play was depicting. ${ }^{61}$ Thus, she decided that the action could not take place in contemporary Paris but "could only take place in eternity"62 or "in a mythical universe where [the events could be] ... poeticized in such a strong way that the suffering will find expression in extremely poetic words." ${ }^{63}$ She had just translated The Eumenides for the Theatre du Soleil, and Aeschylus's play inspired her to revive Greek tragedy for the Bad Blood Scandal. ${ }^{64}$

Faced with the injustice of the Bad Blood Scandal, Cixous's play demonstrates an alternative to prosecution: a ceremony of confession and forgiveness. Cixous claimed to write the play to expose "the gap between Law and Justice," and has said that it "open [s] a kind of ideal and . . very fragile court of justice, where another type of trial could take place and the victims could be heard and listened to." 65

The play begins when the mother of two dead hemophiliac boys leaves the Perjured City (which Cixous said is based on Paris but is intended to be universal) because, echoing Hamlet, it is "rotten to the core." ${ }^{66}$ The play takes place in a cemetery (intended to

$58 I d$. at 90 .

59 Prenowitz, supra note 8, at 20 (quoting Hélène Cixous on the "heart of the subject" of the play).

60 Id. at 18 .

61 Id.

62 Id.

$63 I d$.

64 Id.; see also Fort, supra note 4, at 430. Cixous's translation of the The Eumenides had been produced at the Theatre du Soleil. Cixous, Enter the Theatre, supra note 7, at 29.

65 Fort, supra note 4, at 442.

66 Id. at 437 (" $[\mathrm{I}] \mathrm{t}$ 's the Western world, it can happen, has happened, and is happening in any country in the Western developed world ...."). 
be similar to the City of the Dead in Cairo) where Aeschylus, the Greek playwright known as the Father of Tragedy, is the caretaker. ${ }^{67}$ In addition to its allegorical setting, the play has allegorical and archetypal characters, such as the old King (who represents not only former French President François Mitterand, but also corrupt old power) and Forzza (who represents corrupt new power and just plain evil, similar to Iago in Othello) ${ }^{68}$

Structurally, the play has characteristics of a Greek tragedy. In addition to a chorus composed of outlaws living in the cemetery, it has Aeschylus as a main character and the return of the Furieshorrific Medusa-like goddesses who avenge murder by chasing wrongdoers to the ends of the earth ${ }^{69}$ Cixous's play is filled with allusions to other classical Greek tragedies, to Shakespearean tragedy (especially to Hamlet's rotten kingdom), as well as to the Bible. ${ }^{70}$ Some very obvious biblical references include names-for instance, the Mother's dead children are named after the prophets Daniel and Benjamin, and their last name is Ezekiel. There are also biblical allusions to the flood as well as to Belsazar's writing on the wall.

Like Shakespearean tragedies, The Perjured City incorporates comic relief. For instance, in scene 19, the Chorus becomes annoyed with the Furies and asks, "Could you please stop screeching for one second? / And let us think? Just one second! / You are not from here! You don't understand a thing about this place."71 And the Furies respond, "Io! Screeching! Me! Already so vulgar! / Io popoï! Not from here! Why don't you call me a metic, an Arab, / A resident alien!"72 Although this dialogue is funny, it brings up a serious theme in the play: how dominant patriarchy "others" people just as the chorus "others" the Furies. Cixous was personally familiar with this "othering" because she was raised as a Jew in the Arab part of French Algiers, and she and her family had been treated as "other." ${ }^{3}$ Moreover, she saw that the medical system

67 Id. at 443

68 Id. at 437, 439 ("the originary figure of Evil in politics").

69 Lois SPatz, Aeschylus 125 (1982) (noting that "[a]ccording to the Life of Aeschylus this spectacle was so terrifying that pregnant women in the audience aborted at the sight").

70 Fort, supra note 4, at 445. Cixous has stated that she incorporates all these sources because "the time of the poet is not a linear time, it is a marvelously anachronic time ...." Id.

71 Cixous, The Perjured City, supra note 3, at 172.

72 Id. at 173 .

73 Lan Blyth \& Susan Sellers, Hélène Cixous: live Theory 10 (2004); see also Cixous, Enter the Theatre, supra note 7, at 25. 
made hemophiliacs "other," a special class. ${ }^{74}$

As the play opens, the Mother recalls the trial of the doctors, and curses the legal system. She says that she "want[s] neither vengeance nor this foul thing [settlement] / That you recommend"; rather, she "want[s] to be a violent red / That terrifies people's gaze." ${ }^{75}$ Early in the play, smooth-talking lawyers come to the cemetery to offer the Mother a settlement. ${ }^{76}$ The lawyers-portrayed as unethical-know that everything has a price, including death and grief. ${ }^{77}$ They counter the Mother's view of injustice with their own view of injustice, which is that their doctor-clients are in prison, but they are not guilty because they did not kill the children, they "los $[t]$ them."78

At this point, the Greek Furies return from the underground to avenge the Mother. At the end of the classic Greek play by Aeschylus The Oresteia, the Furies went underground and became the benevolent Eumenides who blessed the house. ${ }^{79}$ The Furies had been hounding Orestes for the murder of his mother Clytemnestra, but they were persuaded to go underground by Athena after she promised to replace revenge with a system of justice by court trial. ${ }^{80}$ In Orestes's trial, the jurors' vote was evenly split and Athena broke the tie to acquit Orestes. ${ }^{81}$

In The Perjured City, the Furies return because they say Athena has not kept up her end of the bargain of providing justice: "Nothing has changed ... / The tears of mothers are still flowing." ${ }^{2}$ So, the Furies capture the doctors, known as $\mathrm{X} 1$ and $\mathrm{X} 2$, with orders to "bring them back alive." ${ }^{83}$ The Furies want to murder the doctors, but the Mother wants them "to die . . of shame." 84 Eventually,

74 See infra text accompanying notes 121-122.

75 Cixous, The Perjured City, supra note 3, at 101.

76 Id. at 95.

77 Id.

78 Id. at 96 (emphasis added).

79 Afschylus, supra note 5, at 275; see also Cixous, The Perjured City, supra note 3, at 110-11; Fort, supra note 4, at 426.

80 Aeschruus, supra note 5, at 261; see also Cixous, The Perjured City, supra note 3, at 110-11; Fort, supra note 4, at 426.

81 Aeschylus, supra note 5, at 264.

82 Cixous, The Perjured City, supra note 3, at 111. Cixous writes, "For the past 5000 years, no more Furies / And just look at this planet, what a state it's in!" Id. at 109. In an interview, Cixous has said that "the Furies were obliged to return in 1994 after 3500 years underground" to show "that (1) "nothing has changed on this earth, aside from the telephone'; (2) but the Evil of Democracy has invented new forms of contempt." Fort, supra note 4, at 429.

83 Cixous, The Perjured City, supra note 3, at 114.

84 Id. at 118 . 
with Aeschylus acting as a mediator, the Mother settles on a ceremony to allow the victims to proclaim their indignation. ${ }^{85}$

In this ceremony, which takes place in the cemetery, all the Mother wants is for the doctors to say, "Forgive me." ${ }^{86}$ Urged by their lawyers, the doctors continue to profess their innocence. ${ }^{87}$ Eventually, the Chorus tells the lawyers that they are leading their clients to disaster because they are not in a courtroom, but under the stars, where "we don't give a damn about the law. / What we seek is justice." ${ }^{8}$ The ceremony ends when the doctors refuse to confess. As the Furies comment, the doctors "know[ ] neither terror nor pity. / That is why your tragedy is so tragic." 89

At the play's end, the newly elected president-who won in part because of sympathy for the hemophiliacs (in actuality, Mitterand lost reelection following the Bad Blood Scandal)-orders the Mother to come back to the City and accept compensation..$^{90}$ When she refuses, he orders the cemetery flooded, purportedly to "cleanse" it of all the transients living there. ${ }^{91}$

Cixous has indicated that it is a tradition at the Theatre du Soleil that she does not write the ending of the play "until the last days of the rehearsal." ${ }^{2}$ She said that when the actors "discovered the last scene [the deaths caused by the flood], they were paralyzed with terror and grief. It was worse than The Eumenides." "93 Before she wrote the ending, she and the actors agreed to a "continuation" of the play: In the "Prelude" and "Epilogue" following the flood, the goddess Night leads the Mother, children, and Aeschylus in a walk across the night sky - the High City. ${ }^{94}$ The Mother is ecstatic to be reunited with her children. ${ }^{95}$ The characters look down on earth and see "[h] ow small, agitated, threatened we are." ${ }^{96}$ The Mother speaks to the audience in closing: "Our play is over. May yours begin. / It is your turn to insist that what is just / Comes to pass justly. / In memory, / I leave you my story with its taste of tears

\footnotetext{
85 Id. at 119 .

86 Id. at 141 .

87 Id. at 141-49 (the ceremony includes a comic account of the doctors' defense).

88 Id. at 146.

89 Id. at 170 .

$90 \mathrm{Id}$. at 172 .

91 Id. at 176.

92 Cixous, Enter the Theatre, supra note 7, at 34.

93 Id.

94 Cixous, The Perjured City, supra note 3, at 179-83.

95 Id. at 182. Night says, "And you, the Mother, I don't hear your voice, / Here you are, triumphant, licking your kittens and nibbling at their chins. / Say something. If you don't, our friends will worry." Id.

96 Cixous, Enter the Theatre, supra note 7, at 34.
} 
and milk." 97

The play has a tragic ending, but it fulfills the traditional Aristotelian definition of tragedy, which is to arouse pity and fear and act as a catharsis. ${ }^{98}$ Certainly, it was Cixous's intent to provide catharsis for the families of hemophiliacs by providing a forum to show the truth. Because prosecution of the doctors resulted in very low sentences, justice was not served. Cixous stated:

What The Perjured City aims at is clearly explained by the chorus. They say the past trial was bad, it didn't solve anything, which is exactly what happened in reality. The doctors were sentenced to four years in prison. After serving the four years, they are now free and thriving, while hemophiliacs go on dying. The Perjured City wants to try and open another scene or stage where more of the truth of justice is evinced. ${ }^{99}$

The play provides catharsis for the victims and is a forum to spur society's thinking about justice and alternatives to prosecution. The play also provides an avenue in which all parties-not just the criminals, but also victims-can have their say. Cixous contrasts this with court trials, which have the opposite effect: "in real life, the tribunals are there to repress. To repress the criminal, to repress the victims." 100 In tragedy, there is the possibility of catharsis, and when 50,000 or 100,000 people view the tragedy, they "share the same language ... [and] the same dream. This is ethically and politically powerful." 101

Just as ancient Greek tragedy, such as the Oresteian trilogy, provided a forum to re-enact and re-negotiate society's law, so too does contemporary drama such as The Perjured City. Both are "the enacted sites where Athens [or Paris] gathers to change itself into something new. The theatre of Dionysos is the place where the polis projects itself toward the future." ${ }^{102}$

97 Cixous, The Perjured City, supra note 3, at 182-83.

98 See William Harmon \& C. Hugh Holman, A Handbook to Literature 511-13 (9th ed. 2003).

99 Fort, supra note 4, at 442.

100 Id. at 441.

101 Prenowitz, supra note 8, at 224 (notes to the play indicate that 51,000 people saw the French production of the play).

102 Gray Kochhar-Lindgren, Naming the Abyss: Aeschylus, the Law, and the Future of Democracy, 4 Angelaki: J. Theoretical Human. 127, 131 (1999). 
III. Transition from Orestelan Prosecution to Nonprosecution Alternatives: "The Logic of Law Will Never Make Sense of the Illogic OF GENOCIDE." 103

The Perjured City's confession ceremony replaces the prosecution model of the Oresteian trilogy. The Oresteian trilogy illustrates the transition from vengeance to prosecution. When Aeschylus wrote the play, the ancient system of blood revenge had been replaced by prosecution in the first homicide court, the Areopagus. ${ }^{104}$ So, the Greek word for justice dikè shifted in meaning from "vengeance" or "an act of recompense"105 to the Fifth Century B.C. establishment of the Areopagus when dikè meant "that which is right"-trial by jury. ${ }^{106}$ When the state began to prosecute wrongdoers, it took over the individual's desire for vengeance, and public punishment was viewed as retribution. As Martha Minow explains Jean Hampton's argument: "The ideal is equal dignity for all persons. Through retribution, the community corrects the wrongdoer's false message that the victim was less worthy or valuable than the wrongdoer." 107 But retribution also needs limits.

In some circumstances, such as genocides or mass atrocities, it may be impractical or impossible to prosecute all the wrongdoers. Moreover, in these circumstances, retribution may not be able to bring relief to victims or to society in coming to terms with the past. ${ }^{108}$ An alternative to retribution might include restorative or therapeutic justice. Archbishop Desmond Tutu has defined restorative justice as having as its "central concern ... not retribution or punishment, but the healing of breaches, the redressing of imbalances, the restoration of broken relationships and a seeking to rehabilitate both the victims and the perpetrator, who should be

103 Martha Minow, Between Vengeance and Forgiveness: Facing History After Genocide and Mass Violence 5 (1998) (quoting Lawrence L. Langer, Admitting tHe Holocaust 171 (1995)).

104 Spatz, supra note 69, at 2-3; see also Gray Kochhar-Lindgren, supra note 102, at $132 \mathrm{n} .2$ (tracing scholarly views on Aeschylus's position about justice reforms).

105 Marie Adornetto Monahan, The Role of Women in the Development of the First Court of Justice, 25 CumB. L. Rev. 577, 579 (1994-1995).

$106 I d$. at 577.

107 Minow, supra note 103, at 12 (quoting Jean Hampton in Jefrrie G. Murphy \& Jean Hampton, Forgiveness and Mercy 157-61 (1988)); see also Teresa Godwin Phelps, Shattered Voices: Language, Violence, and the Work of Truth Commissions 43 (2004) (quoting Jeffrie Murphy arguing, "One reason we so deeply resent moral injuries done to us is not simply that they hurt us in some tangible or sensible way; it is because such injuries are also messages - symbolic communications. They are ways a wrongdoer has of saying to us, 'I count but you do not.'").

108 Godwin PhelPs, supra note 107, at 13. 
given the opportunity to be reintegrated into the community he has injured by his offense."109 Thus, Cixous's play alludes to Aeschylus's trilogy to show the transition from prosecution to a new meaning of dikè as confession and forgiveness when retribution has failed in the context of genocide. As one of the characters in The Perjured City comments:

So, don't hope.

She will never come, the beauty with long curls,

She will never come, the divine one with straight back

And nostrils flaring in fury-

We used to call her "Dikè"

But she would not answer us.

The ones we wait for never come,

It's always like that.

The Messiah doesn't come.

Justice doesn't come,

The beautiful gods do not respond. ${ }^{110}$

The appropriateness of nonprosecution alternatives depends on the goals a society wants to implement. Our standard goals for criminal justice include revenge or retribution, deterrence, rehabilitation, incapacitation, compensation, restorative justice, and social solidarity. ${ }^{111}$ Some goals are best achieved through nonprosecution-for instance, when the Mother in the play rejects retribution and compensation as unjust and opts for restorative justice through the ceremony of confession and forgiveness. Likewise, some countries dealing with mass atrocity, such as South Africa, have also chosen restorative justice. What goals are they selecting? Possible goals include truth, accountability, forgiveness, catharsis, and reconciliation. ${ }^{112}$ Martha Minow sees the goals as primarily therapeutic - to come to terms with the past, and to heal

109 Desmond Tutu, No Future Without Forgiveness, 16 New Perspectrves Q. 29 (1999) (interview); see also Jonathan Allen, Between Retribution and Restoration: Justice and the TRC, 20 S. Afr. J. PHIL. 22 (2001) (distinguishing transitional justice and restorative justice).

110 Cixous, The Perjured City, supra note 3, at 116. In an interview, Cixous expresses a Derridean sense of justice: "My play is entirely in agreement . . . [with Heidegger's view] showing etymologically that justice is always adikia, always out of joint ... that it can never exist, that it has to do also with the present itself, the present not being present or being delayed .... Law only provides legal satisfaction, which is really nothing for the individual who hungers for justice. Justice belongs to another realm completely, it is the dream-part of our lives." Fort, supra note 4, at 442.

111 See generally Wayne R. LaFaVe, et al., I Substantive Criminal Law $§ 1.5$ (2d ed. 2003).

112 Minow, supra note 103 , at 9. 
victims and perpetrators. ${ }^{113}$ As Tutu stated:

Our nation sought to rehabilitate and affirm the dignity and personhood of those who for so long had been silenced, had been turned into anonymous, marginalized ones. Now they would be able to tell their stories, they would remember, and in remembering would be acknowledged to be persons with an inalienable personhood. ${ }^{114}$

In Cixous's play, the goals are likewise restorative. The Mother wants conditional forgiveness based on the doctors' confessions. However, the doctors refuse to confess, so the ceremony fails, at least on one level for the Mother. Nevertheless, since the Mother's story is told, the ceremony can be viewed as a success on another level-because there is a therapeutic effect in telling one's story. ${ }^{115}$ The premise of the restorative power of truth-telling is the same in the setting of the justice system as in psychotherapy: "In both settings, the goal is not exorcism but acknowledgement."116 A victim who tells his or her story benefits from the dignity afforded by the process, as well as from the acknowledgement of grief, and hopefully from letting go of the past in order to build a future. ${ }^{117}$ These benefits also apply to a public telling. Although the ceremony in the play was semi-public because it took place at night in a cemetery among gods and goddesses, ${ }^{118}$ the play itself was a public telling of the Bad Blood Scandal for all members of the audience and all readers. Thus, if we consider the larger goal of the play-as an avenue of catharsis not for the characters in the play, but for the audience (the hemophiliacs and their families) - the play is therapeutic. The play provides a forum to show the truth-to show, as Cixous said, " $[\mathrm{t}]$ he enigma of wickedness, of human cruelty . . . . Theater is the place of Crime ... the place of horror, also the place of Forgiveness." 119

While telling a story of genocide may be therapeutic to both the victim and to society, how does forgiveness fit into justice and into nonprosecution alternatives, especially in the context of extraordinary crimes or collective violence? The Mother in the play, like the Japanese hemophiliacs and their families, ${ }^{120}$ wanted more

113 Id. at 21.

114 Desmond Tutu, No Future Without Forgiveness 30 (1999).

115 Minow, supra note 103, at 66; see also Godwin PHELPS, supra note 107, at 54-56.

116 Minow, supra note 103, at 66.

117 Id. at 66-67.

118 See Prenowitz, supra note 8, at 5 ("There is no theatre without gods.").

119 Hélène Cixous, The Place of Crime, The Place of Forgiveness, in THE HÉlÈnE Cixous READER 149, 154 (Susan Sellers ed., 1994).

120 See supra text accompanying notes $34-40$. 
than anything else for the doctors to confess and to ask forgiveness. Although crimes against the hemophiliacs might seem like ordinary crimes, Cixous saw them as extraordinary, comparable to genocide. In her view, the hemophiliacs were treated like an ostracized class, "an inferior and bothersome race," as she said, "destined for a reservation, a park, a camp."121 Cixous, therefore, considered the hemophiliacs as a small race that was annihilated, making this point through many allusions to the Holocaust and to French Vichy officials. ${ }^{122}$

The following parts of this Article consider the theoretical debate surrounding forgiveness as an alternative to prosecution, before turning to examples of restorative justice in the context of South Africa's Truth and Reconciliation Commission in order to discuss the benefits and the problems of forgiveness and restorative justice.

\section{Theoretical Considerations of Forgiveness as a Nonprosecution Alternative: "All I Ask Is This: Two Words." 123}

Cixous's solution to the impossibility of justice for this extraordinary Bad Blood Scandal was the creation in the play of the ceremony of confession and forgiveness. The Mother's primary concern is for the doctors to say, "Forgive me." ${ }^{24}$ Like the victims in Japan's Bad Blood Scandal, ${ }^{125}$ the desire for forgiveness (and especially for an apology) is a strong refrain in victim's rights. ${ }^{126}$ As discussed in more detail in Part V, forgiveness allows victims to

\footnotetext{
121 Fort, supra note 4, at 433.

$122 I d$. at $432-33$.

123 Cixous, The Perjured City, supra note 3, at 141. The two words are "Forgive me." Id.

125 See supra, text accompanying notes $34-40$.

126 See Stephanos Bibas \& Richard A. Bierschbach, Integrating Remorse and Apology into Criminal Procedure, 114 YALE L.J. 85, 113-16 (2004). Although this Article cites scholarship concerning the restorative justice roles of victim-offender mediation, especially the necessity of apology, it does not include a discussion of the debate surrounding victim-offender mediation, see, e.g., Richard Delgado, Prosecuting Violence: $A$ Colloquy on Race, Community, and Justice, 52 STAN. L. Rev. 751 (2000), primarily because the context of collective violence differs in many respects from that of ordinary crime. One difference is that offenders of ordinary crimes do not receive amnesty, whereas offenders in extraordinary crimes may receive amnesty. Thus, many proponents of victim-offender mediation view "remorse and apology [as] . . . neither substitutes for punishment nor cruel, ostracizing forms of punishment. Instead, remorse and apology should supplement but not supplant punishment." Bibas \& Bierschbach, supra, at 125. This view is not practical for collective violence, as discussed above. Jeffrie Murphy also distinguishes individual and collective forgiveness in his scholarship address-
} 
"reassert their own power and reestablish their own dignity, while also teaching wrongdoers the effects of their harmful actions." ${ }^{27}$ It allows bonds to be reestablished because, by forgiving, the victim can "reconnect and recognize the common humanity of the other." 128

The theoretical debate about forgiveness as an alternative to prosecution presents three questions. First, should forgiveness be conditional or unconditional-that is, should it be based on confession and a request for forgiveness or should it be given unconditionally? Second, does forgiveness even belong in the social realm, or should it be reserved for the private realm? And third, does forgiveness necessarily lead to forgetting?

\section{A. Forgiveness as Conditional or Unconditional}

In the play, the Mother does not seek revenge or retribution; she wants conditional forgiveness based on the doctors' request for forgiveness. If the doctors show no repentance and remorse, then the Mother cannot forgive them. Under such a view, forgiveness is conditional. Jeffrie Murphy has pointed out that by forgiving, one risks losing self-respect or respect for the moral order, and that one way to resolve this problem is for the wrongdoer to sincerely request repentance. ${ }^{129}$ One problem with conditional forgiveness is the possibility that the offender will fake repentance. ${ }^{130}$ Another problem occurs when the offender refuses to show repentancesuch as the doctors in the play. The victim who wants conditional forgiveness cannot forgive, and sometimes forgiveness is essential in order for the victim to heal grief and get on with life. ${ }^{131}$

These problems with conditional forgiveness lead some to claim that forgiveness does not have to be conditional. Some argue that it is the better view, perhaps the utopian view, that forgiveness should be unconditional. The French philosopher Jacques Derrida has argued for unconditional forgiveness. He has said that "forgiveness forgives only the unforgivable," meaning that forgiveness "should not be [ ] normal, normative, normalising," but should be exceptional. ${ }^{132}$ According to this view, if we are "prepared to

\footnotetext{
ing individual (or interpersonal) forgiveness. See JefrRie G. Murphy, Getting Even: ForgIVENESS AND ITS Limits 5 (2003).

127 Minow, supra note 103, at 15.

128 Id. at 14 .

129 MuRPHy, supra note 126, at 35.

130 Id. at 19.

131 Id. at 14, 18-19.

132 Jacques Derrida, On Cosmopolitanism and Forgiveness 32 (Simon Critchley
} 
forgive what appears forgivable," then the necessity of forgiveness disappears. ${ }^{133}$ Derrida insists on the paradox that forgiveness forgives only the unforgivable. He disagrees with the notion that some acts are unforgivable. ${ }^{134}$ If we insist on conditional forgiveness, we are forgiving someone who has been changed by repenting, and this person is not the same person who committed the crime. ${ }^{135}$

Moreover, requiring conditional forgiveness leads to problems in determining who has the power to forgive someone-the victim, the state, God? ${ }^{136}$ Derrida concedes that the utopian view that forgiveness should be unconditional does not really work in the public realm if we want conditional forgiveness in order to have reconciliation. He thus criticizes the intervention of the state in forgiveness because "forgiveness must engage two singularities: the guilty . . . and the victim. As soon as a third party intervenes, one can again speak of amnesty, reconciliation, reparation, etc., but certainly not of pure forgiveness." ${ }^{137}$ This leads into the second question.

\section{B. The Social Versus Private Realm}

The second question is whether forgiveness even belongs in the social realm or whether it should be reserved for the private realm. While Derrida envisions forgiveness in the social realm without state intervention, Julia Kristeva argues that forgiveness belongs only in the personal realm. ${ }^{138}$ She agrees with Hannah Arendt that the social sphere is reserved for judgment, not forgiveness, because the community is "founded on law and punishment." ${ }^{39}$ In this view, the way for society to deal with extraordinary crime is to prosecute perpetrators in international

\& Richard Kearney eds., Mark Dooley \& Michael Hughes trans., Routledge 2001) (1997).

$133 I d$.

134 Id. at 36-38; see also, e.g., Interview by Alison Rice with Julia Kristeva, Forgiveness: An Interview, 117 PMLA 281, 283 (Mar. 2002). While Kristeva believes forgiveness forgives the unforgivable, she believes forgiveness can take place only in the personal realm because it is impossible for society to "pardon criminals like Barbie or Pinochet without judgment and punishment." Id.

135 DERrIDA, supra note 132, at 38-39; Rice, supra note 134, at 283 (Kristeva urges conditional forgiveness).

136 DERRIDA, supra note 132 , at $38,41-42$.

137 Id. at $42-43$.

138 Rice, supra note 134, at 282.

139 Id. 
tribunals. ${ }^{140}$ If perpetrators are forgiven in the social realm, it appears that they are elevated to the position of "someone worthy of forgiveness." 141

But the view that forgiveness belongs only in the personal realm may be too narrow because it assumes that forgiveness excludes subsequent punishment and that choosing forgiveness is not a legal goal but merely a personally therapeutic goal. However, as discussed above, the justice system is founded on many goals besides punishment, including restorative justice. Forgiveness might be essential not just for a victim to heal and move on, but also for a society to move on after a mass atrocity. ${ }^{142}$ And while forgiveness does not necessarily have to be a substitute for punishment, in the context of restorative justice, a government often does pardon or grant amnesty to those whom it forgives. ${ }^{143}$

The next part of this Article explores the South African Truth and Reconciliation Commission, which did not require apology and forgiveness, as an example of restorative justice. And while it shows that the social sphere can be the arena of forgiveness, a sovereign cannot force a victim to forgive. ${ }^{144}$ Phelps relates a TRC incident in which the widow was present at her husband's killer's testimony, and when asked if she could forgive him, she stated through translation, "No government can forgive.' Pause. 'No commission can forgive.' Pause. 'Only I can forgive.' Pause. 'And I am not ready to forgive.' "145 Though it cannot force forgiveness, a sovereign can provide a forum for forgiveness, such as the ceremony for the Mother and doctors in Cixous's play.

\section{Forgiveness and Forgetting: "Those Who Forget the Past Are Doomed to Repeat It." 14}

The third consideration in this theoretical debate is whether forgiveness necessarily leads to forgetting. ${ }^{147}$ The fear is that if so-

140 Id. at 283; see also Peter Brooks, Kristeva's Separation of Spheres, 117 PMLA 296, 296 (2002).

141 Minow, supra note 103, at 16.

$142 \mathrm{Id}$. at 14 .

143 Id. at 15 .

144 Susan Vanzanten Gallagher, "I Want to Say: / Forgive Me": South African Discourse and Forgiveness, 117 PMLA 303, 304 (2002); MiNow, supra note 103, at 19-20.

145 Godwin Phelps, supra note 107, at 112 (quoting Timothy Garton Ash, True Confessions, N.Y. Rev. Books, July 17, 1997, at 36-37).

146 TuTu, supra note 114 , at 29 (quoting the well-known words of George Santayana).

147 Gallagher, supra note 144, at 303 (contrasting the TRC with Chile's blanket amnesties "which encouraged social amnesia about past abuses"). 
ciety forgives its worst criminals, it is integrating them and accepting their acts-it is sanctioning forgetting. ${ }^{148}$ So, if society refuses forgiveness, especially to those some consider unforgivable, society can continue to remember and condemn their acts. The tension is that even if society refuses forgiveness, "individual victims may need to forgive . . . to get on with their lives."149 And for that matter, a society may need to forgive to get on with its future. One obvious option is to forgive-but not to forget. While forgiveness may allow individuals and society to come to terms with the past and accomplish a therapeutic goal, society can nonetheless accomplish "the burden of remembering" through memorials and through works of art and literature, such as Cixous's play. ${ }^{150}$ Such works memorializing genocide and mass atrocity may be seen as creating new social narratives that "acknowledge[ ] and lament[ ]" violence. ${ }^{151}$

\section{Restorative Justice: South Africa's Truth and RECONCILIATION MODEL}

Cixous's play offers an alternative form of legal justice-but is it just? Perhaps we can answer that by considering what this alternative might look like through South Africa's Truth and Reconciliation Commission. The TRC was established in 1995 to effectuate the country's transition from apartheid-a system that the United Nations had labeled a crime against humanity-to a democratic state. ${ }^{152}$ The restorative justice goals of the TRC were to establish the truth about past violence, to restore the victims' dignity, to make violators accountable, to understand and reintegrate violators, and to allow for collective healing and restoration. ${ }^{153}$ Like the

148 See generally Jean Hampton, Correcting Harms Versus Righting Wrongs: The Goal of Retribution, 39 UCLA L. REv. 1659, $1677-78$ (1992); MINOw, supra note 103, at 15-16. 149 Cary Nelson, Forgiveness and the Social Psyche, 117 PMLA 317, 318 (2002).

150 Id.; see also Erin Daly, Reparations in South Africa: A Cautionary Tale, 33 U. MEм. L. REv. 367, 383 (2003).

151 Gallagher, supra note 144, at 305 (noting the many South African works of literature inspired by the TRC).

152 Albert L. Sachs, Honoring the Truth in Post-Apartheid South Africa, 26 N.C. J. INT'L L. \& Com. Reg. 799, 801-02 (2001) [hereinafter Sachs, Honoring the Truth]. In discussing the origins of the TRC, Sachs tells that the African National Congress (ANC) had debated whether acts by ANC members should also be subject to scrutiny and decided that all human rights violations in South Africa should be scrutinized: "So, paradoxically, the idea of a Truth Commission in South Africa emerged because of the ANC's desire to build its democracy with clean hands and without secrets." Id.

153 See Bronwyn Leebaw, Restorative Justice for Political Transitions: Lessons from the South African Truth and Reconciliation Commission, 43 Contemp. Just. REv. 267, 272 (2001). 
characters in Cixous's play, the African National Congress (ANC) chose restorative justice over retributive justice.

Archbishop Desmond Tutu gives three reasons in his book No Future Without Forgiveness for why retributive justice was not possible. The change from apartheid to democracy occurred through constitutional negotiations, rather than through revolution. ${ }^{154}$ In addition, criminal prosecution would unreasonably burden the "already strained judicial system."155 Finally, restorative justice would provide a better means of uncovering the truth, especially under circumstances in which "the only witnesses to events who were still alive were the perpetrators and they had used the considerable resources of the state to destroy evidence and cover up their heinous deeds." 156

The TRC was based on the South African concept of ubuntu (the idea that a human is realized through recognizing others as persons). ${ }^{157}$ The new constitution also incorporated the concept of ubuntu, and in establishing the TRC, provided for three committees: the Human Rights Violations Committee, which gathered statements from more than 21,000 victims of gross human rights abuses that occurred between 1960 and 1994 and chose a representative sampling for public narratives; the Reparation and Rehabilitation Committee, which did not have the power to make reparations, but made recommendations to Parliament; and the Amnesty Committee, which received over 7000 applications for amnesty and ultimately granted only a small number. ${ }^{158}$ Amnesty could be granted only if the perpetrator gave full disclosure and if the act was associated with political objectives. ${ }^{159}$ In describing the events that inspired the amnesty provisions, Justice Albie Sachs explained that during the first democratic elections, there were threats of bombings, and that security and military forces had been promised by then-President Frederik W. De Clerk that they would

154 Turu, supra, note 114, at 20-21. Tutu observes, "[w]hile the Allies could pack up and go home after Nuremberg, we in South Africa had to live with one another." Id. at 21 .

155 Id. at 22.

156 Id. at 23; see also, Godwin PHelps, supra note 107, at 61.

157 Heidi Grunebaum, Talking to Ourselves "Among the Innocent Dead": On Reconciliation, Forgiveness, and Mourning, 117 PMLA 306, 309 n.1 (2002). See also TuTu, supra note 114, at 31 (pointing out the difficulty of translating ubuntu, which Tutu says refers to "the very essence of being human . . . . It is to say, 'My humanity is caught up, is inextricably bound up, in yours." ).

158 See Minow, supra note 103, at xii, 53, 167; Leebaw, supra note 153, at 278.

159 Minow, supra note 103, at 55-56; see generally Anurima Bhargava, Defining Political Crimes: A Case Study of the South African Truth and Reconciliation Commission, 102 Colum. L. REv. 1304 (2002) (critiquing the TRC's definition of a political crime). 
have amnesty, but the security and military forces were not going to protect the election if they were going to be prosecuted afterwards. ${ }^{160}$ Thus, Sachs proposed to the ANC that an amnesty provision be included, and that provision was added as a "postscript to the Constitution." 161 Unlike other truth commissions, amnesty in South Africa was not blanket amnesty and a finding of state action was not required, but rather just a finding that the act was associated with political objectives. ${ }^{162}$

Criticisms of the TRC include the argument that the TRC should not grant amnesty to perpetrators of gross human rights violations. ${ }^{163}$ For example, an editor of the Johannesburg Star wrote, "[i]t stinks to high heaven . . . to imagine that after confessing, these people who committed the most horrendous crimes will then be patted on the shoulder by the TRC."164 Thus, although the ANC provided for a system of restorative justice, not retributive justice, not all victims of apartheid accepted this choice. Some people did not want to give up retributive justice. In her book about Nelson Mandela, Cixous refers to this need to vindicate (and not forgive) gross human rights violations. For instance, Cixous's feelings about the killer and especially about the doctors who ignored the suffering of activist Steve Biko reflect the feelings of many victims and families of victims:

[W] hat continues to cause me suffering is those who did not die, and whom nothing will kill, and whose names follow: Dr. Lang, Dr. Tucker, and Dr. Hersch, because they contemplated smoking the death-throes of the man whose brain was crushed and who could no longer do anything on purpose ....

And because three times in each day they said .... it's nothing . . . "Get down off your cross, joker." Signed: the doctor.

And behold how ... they are still alive on this earth, in this very moment, exactly as though they were born and had just been born from the belly of a human woman .... .

I name them, in the hope that a huge number of curses is

160 Sachs, Honoring the Truth, supra note 152, at 803-04 (noting that the forces believed "it was inhuman to ask them to guarantee the security of the elections if they would end up going to jail afterwards.").

161 Id. at 803.

162 See Bhargava, supra note 159 , at 1307-08.

163 See Wilhelm Verwoerd, Toward a Response to Criticisms of the South African Truth and Reconciliation Commission, in Dilemmas of Reconciliation: Cases and Concepts 245 (Carol A.L. Prager \& Trudy Govier eds., 2003) (describing various criticisms of the TRC and illustrating argument with political cartoons published during the hearings).

164 Corinna Schuler, South Africa: Wrestling with Forgiveness, Christian Sci. Monitor, July 9, 1999, at 1 (quoting Mathetha Tsedu, Deputy Editor of the Johannesburg Star). 
more efficient than a small number of curses. I hope. And that in Hell they live on Steve Biko Street. ${ }^{165}$

Cixous's desire for retribution was voiced by some members of the black community during the TRC hearings. ${ }^{166}$

However, as Cixous admits, although we may have a desire for retribution or vengeance, ${ }^{167}$ rationally, we have suppressed the old mechanisms for acting out of revenge. Society no longer follows the principle of an eye for an eye, but yet Cixous suggests that we can express revenge through our words:

This is one of the questions in the play, of course [whether we should continue nurturing our vengeance]. But it is to be ruled out .... We have renounced vengance [sic] and signed the contract with Athena. But what we impose upon ourselves by day-we dream about it at night. We are not at peace. We do not want to believe that those who kill their mother will enjoy a prosperous life like Orestes. I'm against capital punishment. Vengeance is a snare. When you think that you are taking revenge, you simply pour oil on the fire. But it's really the fact that they were vociferating that I miss. They would shout, they would express reproach in a way that now and then we need. We need the wording of indignation. That's part of their function, which I think is sadly lacking nowadays, and which is left for poets. Who else now flares up, except poets? ${ }^{168}$

Cixous's question of "Who else now flares up" can be answered by "not just poets, but by any victim who can tell his or her story." Cixous's play may be considered vengeance because it allows the mother to express "the wording of indignation." 169 Similarly, those victims who filed reports and testified during the TRC hearings also had the chance to express indignation. ${ }^{170}$ In other words, even though the TRC chose restorative justice over retributive jus-

165 Cixous, Manna, supra note 6 , at $31-32$; see also Murphy, supra note 126 , at 20 (arguing that as part of our "duty to support . . . the moral order" we risk being "complicitous in evil" if we do not show resentment).

166 Mathatha Tsedu, Questioning if Guilt Without Punishment Will Lead to Reconciliation: The Black Press Relieves Its Own Horrors and Seeks Justice, 52 NiEman Reports 56, 57 (Winter 1998).

167 See Robert C. Solomon, Justice $v$. Vengeance: On Law and the Satisfaction of Emotion, in The Passions of Law 123, 131 (Susan A. Bandes ed., 1999) ("Vengeance is a species of retribution.").

168 Fort, supra note 4, at 448.

$169 I d$. While the entire play can be seen as fulfilling this function, the beginning, however, especially expresses indignation in a ninety-five-line soliloquy by the Mother cursing the doctors and the city. Cixous, The Perjured City, supra note 3, at 91-93.

170 See Godwin Phelps, supra note 107, at 68 (recounting an incident before the TRC in which the mother of the dead victim screamed and threw her shoe at her son's killer). 
tice, the process of allowing victims to tell their stories can be seen as vengeance or retribution. Phelps convincingly argues that because the TRC provided a mechanism by which victims could confirm their "dignity and autonomy," it was a form of retribution. ${ }^{171}$

Another criticism of the amnesty process was that at times "the 'process ... . [went] horribly wrong'" as, for instance, in the testimony of Captain Jeffrey Benzien, who was granted amnesty. ${ }^{172}$ During his testimony before the Amnesty Committee, the men he had tortured were present as questioners, and several times Benzien "turn[ed] the tables again and put[] the victims at the perpetrator's mercy." ${ }^{773}$ Although he also apologized and asked for forgiveness, ${ }^{174}$ some viewed Benzien's amnesty as "'contested and ... illegitimate." "175

In response to such criticism about the amnesty hearings, others, such as Tutu and Sachs, have argued that amnesty was necessary in order for the perpetrators to reintegrate into society, and that the process "cannot be understood simply as reconciliation between the individual victim and the individual perpetrator."176 Moreover, the amnesty hearings were necessary in order to discover the truth surrounding the violations. Minow suggests:

Gathering this information can provide some measure of comfort to the victimized who want to know where a loved one is buried, whether he or she was tortured before dying, who ordered the raid, or whether the suicide note was forged. The collected information from the amnesty applicants will help provide a fuller picture of the past. ${ }^{177}$

$171 I d$. at 61,110 . "Importantly, though, the surrender of [retributive] violence did not exist in a void; it was accompanied by the opportunity to put the harmful experience into words, to shape it into a story, and thus to receive retribution in a different sense, getting back control over the telling and shaping of one's own story." Id.

172 Mark Sanders, Renegotiating Responsibility After Apartheid: Listening to Perpetrator Testimony, 10 Am. U. J. Gender Soc. Pol'y \& L. 587, 590 (2002); see also, GodwiN PHeLPS, supra note 107, at 111 (recounting other instances when things went wrong, such as "former President P. W. Botha's snub of the Commission, with Winnie Mandela's 'things went horribly wrong' nonresponse to the accusations against her, even arrogant countenances on former police and defense force operatives").

173 Sanders, supra note 172 , at 588. Sanders gives the example in which, after one victim had Benzien demonstrate his "wet bag" torture method, "Benzien quietly turn [ed] on him and with one accurate blow, shatter[ed] [his] political profile right across the country. 'Do you remember, Mr. Yengeni, that within thirty minutes you betrayed Jennifer Schreiner? Do you remember pointing out Bongani Jonas to us on the highway?" Id.

174 Id. at 594.

175 Id. at 589.

176 Sachs, Honoring the Truth, supra note 152 at 806.

177 Minow, supra note 103, at 77. 
The truth would not have been revealed in a traditional prosecution because, as Tutu notes, in a criminal prosecution the evidentiary standard would not have revealed the covered-up and lost facts. ${ }^{178}$ And even some of those who criticized the TRC, such as the lawyer who sued the TRC for granting amnesty to the killer of Steve Biko, admitted that it did a better job of uncovering the truth than would have criminal prosecutions. ${ }^{179}$

Because the perpetrators did not receive blanket amnesty, but had to participate as individuals in the truth-telling process by fully disclosing the facts, Sachs notes that " $[t]$ his process puts a face on the cruelty. In South Africa, the perpetrators acknowledge their crimes, and shame is their punishment. ... Shame, however, gradually dissipates as one reintegrates into society." 180 Tutu likewise emphasizes that reintegration is a chief concern of restorative justice:

Here the central concern is not retribution or punishment. In the spirit of ubuntu, the central concern is the healing of breaches, the redressing of imbalances, the restoration of broken relationships, a seeking to rehabilitate both the victim and the perpetrator, who should be given the opportunity to be reintegrated into the community he has injured by his offense. ${ }^{181}$

Another criticism of the TRC concerns forgiveness. Although the TRC did not require apologies or forgiveness in order to grant amnesty, ${ }^{182}$ Archbishop Desmond Tutu, the commission chair, continuously said that South Africa had "no future without forgiveness." ${ }^{183}$ For Tutu, forgiveness was not forgetting, but rather trying to understand the perpetrator, which would in turn, liberate the victim. So, even though forgiveness was not required, "most" perpetrators asked for forgiveness and many, but not all, victims forgave. ${ }^{184}$ Perpetrators who told the truth about violations could say they were sorry and ask for forgiveness. Victims could forgive even if perpetrators did not express contrition. Tutu has written, "we were constantly amazed in the commission at the extraordinary

\footnotetext{
178 Tutu, supra note 114, at 23.

179 Godwin Phelps, supra note 107, at 61 (indicating that the lawyer George Bizos was "a strong supporter of the TRC's work ... [because] in his opinion [it] was able to uncover far more truth than trials would have done.").

180 Sachs, Honoring the Truth, supra note 152, at 808.

181 TuTu, supra note 114 , at 54-55.

182 Id. at $49-50$.

183 Gallagher, supra note 144, at 303; see also TuTu, supra note 114, at 268-82.

184 See Minow, supra note 103, at 77-78; Tutu, supra note 114 , at 50, 144-57.
} 
magnanimity that so many of the victims exhibited." 185

Considering the theoretical considerations raised in Part IV as applied to the TRC, we see that the apologies and forgiveness occurred not in private, but in a very public forum. However, the forgiveness itself was not a public act, but discrete, individual acts. Some were instances of conditional forgiveness, and others were instances of unconditional forgiveness. ${ }^{86}$ Tutu has emphasized that his vision of "no future without forgiveness" did not lead to forgetting, because apartheid has been remembered and reproduced "[i]n a positive rather than a vindictive way" through art, memorials, the renaming of public buildings, and through the Commission Report. ${ }^{187}$

Another set of criticisms focused on the Human Rights Violations Committee (HRV Committee). Victims made 21,298 statements, and of these, "only a small percentage was selected for public hearings." 188 One criticism regarding the HRV Committee was that the TRC focused only on extreme violence and not on ordinary violence, basically ignoring the everyday violence of apartheid, such as "the forced removals, the dispossession of land, the mandatory carrying of passes, the effects of the migrant labor system on black family life." 189 Another criticism was that excluding ordinary violence had a gendered effect because "rural black women [were] the most restricted, exploited and marginalized." 190 In terms of the victims who testified before the HRV Committee, there was criticism that the victims needed psychological counseling, not just the opportunity to tell their story to the TRC; ${ }^{191}$ there was also criticism that the victims were led to believe they would receive reparations, but they did not; ${ }^{192}$ and finally, there was criticism that the victims felt pressured to forgive. ${ }^{193}$

Despite these criticisms, there was a sense that the TRC fulfilled the restorative and therapeutic power of acknowledging vic-

185 Turu, supra note 114, at 27; see also id. at 146-59 (giving examples of forgiveness during the hearings).

186 Id; see also Judith Baker, Truth Commissions, 51 U. Toronto L.J. 309, 317 (2001) (pointing out that forgiveness may be offered based on the "desire to build a just society").

187 Tutu, supra note 114, at 64; see also Minow, supra note 103, at 138.

188 Leebaw, supra note 153, at 278.

189 Mark Sanders, Extraordinary Violence, 3 Interventions: INT'L J. Postcolonial STud. 242, 243 (2001).

190 Id. at 243.

191 Leebaw, supra note 153, at 279.

192 Id.; see also infra text accompanying notes 204-209 (regarding reparations).

193 Id. at 280. 
tims' stories, as Minow and Phelps point out in their discussions about the TRC hearings. ${ }^{194}$ Minow states, "the sheer act of speaking in a setting where you are believed can be affirming for those who have been victimized." ${ }^{195}$ Likewise, Justice Sachs recognized the criticisms of the TRC when he pointed out that the TRC "remains an institution plagued by internal and external disputes"; 196 however, he has predicted the success of the TRC, "as an engine for collective healing, will continue interminably." ${ }^{97}$ In part, this is because the TRC envisioned that its citizens could "come forward and tell stories ... [as] responsible moral agents and no longer passive victims." ${ }^{198}$ Sachs noted that the HRV Committee "served the 'little people' by traveling throughout South Africa and allowing the thousands of people in the townships and in the rural areas to voice their stories." ${ }^{99}$ Similarly, Archbishop Tutu recognized the "arbitrariness" in the limiting definition of "gross violations of human rights" because apartheid itself was judged such a "gross violation of human rights" and "almost all black people could legitimately be designated victims of that system." ${ }^{200}$ However, due to practical considerations, Tutu stated that the TRC had to somehow limit the definition. ${ }^{201}$ Although the Commission had to limit the number of reports, it tried to select representatives of "the broadest possible political spectrum" and held public hearings that were broadcast for the nation and world to hear. ${ }^{202}$ Tutu opened the first hearing by asserting:

We are charged to unearth the truth about our dark past; to lay the ghosts of that past so that they will not return to haunt us. And that we will thereby contribute to the healing of a traumatized and wounded people-for all of us in South Africa are wounded people-and in this manner to promote national unity and reconciliation. ${ }^{203}$

Criticisms were especially strong concerning reparations. Although the TRC recommended both symbolic and financial reparations, most criticism concerned the abysmally low amount of financial reparations actually made. While the TRC recommended

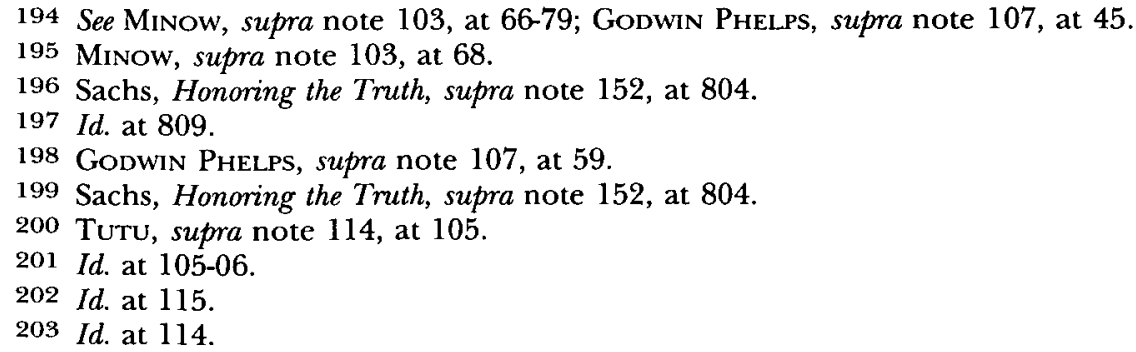


that victims "should receive approximately 21,000 rands every year for six years," ${ }^{204}$ unfortunately South Africa's "government has paid out approximately 2000 rands (then approximately $\$ 300$ ) to each of 17,100 victims." ${ }^{205}$ Even though the government has done an acceptable job carrying out symbolic reparations-such as renaming "roads, schools, and even towns" after heroes-the financial security of victims is bleak. ${ }^{206}$ Both Sachs and Tutu admit that there are problems facing the nation in reconstructing society. ${ }^{207}$ Yet, Sachs states that "human reparations are more essential than monetary ones," and that the liberation from apartheid and the truth about " $[t]$ he bitterly cruel methods used to sustain it, the lies told, and the misinformation and the deceit involved" is "the most significant gain." 208 Thus, while many feel that the TRC failed to structure successful financial reparations to victims, many also agree with Sachs that "the TRC Report itself constitutes a formidable form of reparation." 209

The complexity of judging the effectiveness of restorative justice can be seen in discussions of both the TRC and Cixous's play. Whereas the play can be seen as an example of the failure of restorative justice-because the doctors failed to confess and ask for forgiveness-it can also be seen as an example of the success of restorative justice. The success lies in the truth-telling component in which the Mother successfully told her story of a genocide-a story she had not been able to tell in the criminal justice system. The success also lies in the story being seen by an audience of more than 50,000 people and being read by countless others. The same degree of success has been claimed by the TRC, as indicated above. The public acknowledgment of gross human rights violations and

204 Daly, supra note 150 , at 378 .

205 Id. at 383.

$206 I d$. at $383-84$.

207 See Albie Sachs, South Africa's Truth and Reconciliation Commission, 34 CoNN. L. REv. 1037, 1047 (2002) ("Our country has huge difficulties today: unemployment, HIV, AIDS, crime, many other problems . ...").

In South Africa the whole process of reconciliation has been placed in very considerable jeopardy by the enormous disparities between the rich, mainly the whites, and the poor, mainly the blacks. The huge gap between the haves and the have-nots, which was largely created and maintained by racism and apartheid, poses the greatest threat to reconciliation and stability in our country.

TuTu, supra note 114, at 273-74.

208 Sachs, Honoring the Truth, supra note 152, at 805, 807.

209 Daly, supra note 150, at 390; GoDwiN PhelPs, supra note 107, at 54 (discussing views of the TRC as justice and quoting Justice Richard Goldstone that “ " $t$ ] he public and official exposure of the truth is itself a form of justice." ). 
the public forum in which victims could tell their stories restores victims' human dignity and corrects social wrongs. ${ }^{210}$

\section{Conclusion: "Unjust Justice Is Not an INESCAPABLE FATE"211}

The use of nonprosecution alternatives holds promise for justice for our own past-for slavery, for acts of terrorism, for sexual abuse by priests. But ultimately, the approach a country or society chooses to resolve a particular problem depends on the specific context, on the economic and political considerations, and on the social, cultural, and religious traditions. ${ }^{212}$ Moreover, choosing a particular approach does not need to be exclusive of other approaches. Thus, a communitarian society might place the needs of the community above that of the individual and might choose restorative justice over retributive justice. It is important to realize that what works in one society might not work in another.

For instance, in Rwanda, where it was very expensive and impractical to prosecute all $100,000 \mathrm{Hutu}$ responsible for the genocide of 800,000 Tutsi-and where the prosecutions were not aiding in communal reconciliation and healing-the system of legal justice was destined to be unjust. ${ }^{213}$ The government established a nonprosecution alternative based on the traditional Gacaca system of dispute resolution by elders. ${ }^{214}$ In this system, a perpetrator could confess and plead guilty in exchange for a reduced sentence including community service, but the perpetrator was required to apologize. ${ }^{215}$ Gacaca justice was not available for organizers and leaders-they would still be prosecuted because society considered their crimes unforgivable. ${ }^{216}$ Thus, Rwanda's plan for reconciliation blended contemporary prosecution and the traditional Gacaca system, which itself is a blend of restorative and retributive justice. ${ }^{217}$ Forgiveness did not exclude punishment.

Both The Perjured City and South Africa's Truth and Reconcili-

210 See Minow, supra note 103, at 74-78; Daly, supra note 150, at 396-98.

211 Cixous, The Perjured City, supra note 3, at 105.

212 Minow, supra note 103, at 4.

213 Ironside, supra note 2, at 31-32, 35-38.

214 Id. at 33.

215 Id. at 45.

216 Id. at 41.

217 See Matthew J. Burnett, Remembering Justice in Rwanda: Locating Gender in the Judicial Construction of Memory, 3 SEATTLE J. Soc. Just. 757 (2005) (discussing the criminal prosecutions in both the International Criminal Tribunal for Rwanda as well as Rwanda's national courts and analyzing the effectiveness of the Gacaca system, an ongoing process). 
[Vol. 9:1

ation Commission demonstrate that while a particular society's goals might differ, the critique of these goals through legal analysis and through works of art such as Cixous's play can help close the gap between legal justice and ideal justice-bringing legal justice closer to just justice. 